\title{
The effect of dietary conjugated linoleic acid on the levels of lipids, cholesterol and iodothyronines in the blood of pigs
}

\author{
A. Sechman ${ }^{1,8}$, M. Pieszka ${ }^{2}$, J. Rząsa ${ }^{1}$, W. Migdal ${ }^{3}$, D. Wojtysiak ${ }^{4}$, \\ H. Pustkowiak ${ }^{5}$, B. Živković ${ }^{6}$ and P. Paściak ${ }^{7}$
}

\author{
Agricultural University in Krakow, \\ ${ }^{1}$ Department of Animal Physiology, \\ ${ }^{4}$ Department of Reproduction and Animal Anatomy, \\ ${ }^{5}$ Department of Cattle Breeding \\ al. Mickiewicza 24/28, 30-059 Kraków, Poland \\ ${ }^{3}$ Department of Animal Products Technology \\ Balicka 122, 31-149 Kraków, Poland \\ ${ }^{2}$ National Research Institute of Animal Production \\ 32-083 Balice, Poland \\ ${ }^{6}$ Institute for Animal Husbandry \\ 11080 Zemun, Autoput 16, Serbia and Montenegro \\ ${ }^{7}$ Ecopig Ltd. \\ 42-510 Wojkowice Kościelne, Poland
}

(Received 24 July 2006; revised version 19 March 2007; accepted 2 May 2007)

\begin{abstract}
The aim of the investigation was to study the effect of dietary conjugated linoleic acid (CLA) on the concentrations of lipids, fatty acids and iodothyronines: thyroxine $\left(\mathrm{T}_{4}\right)$, triiodothyronine $\left(\mathrm{T}_{3}\right)$, reverse-triiodothyronine $\left(\mathrm{rT}_{3}\right)$, free $\mathrm{T}_{4}\left(\mathrm{FT}_{4}\right)$ and free $\mathrm{T}_{3}\left(\mathrm{FT}_{3}\right)$ in blood plasma of pigs. The experiment was carried out on 50 fatteners (average liveweight $50 \mathrm{~kg}$ ) divided into 5 groups ( 5 gilts and 5 barrows per group). The pigs were fed a basal diet supplemented with $0,0.5,1,1.5$ and $2 \%$ of CLA isomers. Blood samples were collected from fatteners weighing $105 \mathrm{~kg}$. Supplementation of the diet with CLA did not significantly affect lipid parameters in blood plasma. In comparison with gilts, a significantly higher concentration of triglycerides in barrows was found. In CLA-fed pigs, significant changes in the plasma fatty acid profile were noticed. The higher doses of CLA caused a significant increase in CLA and saturated fatty acids (SFA) with a concomitant decrease in monounsaturated (MUFA) and polyunsaturated (PUFA) fatty acids in blood plasma. Moreover, dietary CLA decreased the $\Delta 9$ desaturase index in a dose-dependent manner, probably as a result of
\end{abstract}

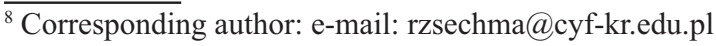


the inhibitory effect of CLA on stearoyl-CoA activity.Only the lowest dose of CLA ( $0.5 \%)$ increased $\mathrm{T}_{4}$ and $\mathrm{T}_{3}$ concentrations in blood plasma of fatteners by 64 and $27 \%$, respectively. There were no significant changes in $\mathrm{rT}_{3}, \mathrm{FT}_{4}$ and $\mathrm{FT}_{3}$ in the plasma of CLA-treated pigs. The results obtained indicate that dietary CLA influenced the fatty acid profile in blood plasma of fatteners without affecting basic lipid parameters. The increase in $\mathrm{T}_{4}$ and $\mathrm{T}_{3}$ concentrations in the blood of CLAtreated pigs suggests that low doses of CLA may stimulate the function of the pituitary-thyroid axis and/or deiodinase activity. On the other hand, the absence of changes in $\mathrm{FT}_{4}$ and $\mathrm{FT}_{3}$ indicates that CLA treatment does not affect thyroid hormone homeostasis in blood.

KEY WORDS: fatteners, CLA, blood plasma, fatty acids, lipid indicators, thyroid hormones

\section{INTRODUCTION}

Conjugated linoleic acid (CLA) comprises an isomeric mixture of linoleic acids [18:2(n-6)] that are polyunsaturated fatty acids differing in the positions and configuration of the conjugated double-bond pairs. Recent years have seen a growing interest in the effect of CLA on animal metabolism and productivity (Dugan et al., 2004). Interest in these investigations has significantly increased in association with the results of in vivo and in vitro studies showing marked physiological activity of CLA that is of great importance in normal body function and health. It has been shown that CLA has antioxidant and antiobesity activity that leads to body weight reduction (DeLany and West, 2000). In other studies, CLA has been shown to protect against atherosclerosis and to exert a hypocholesterolaemic effect (Corino et al., 2002). In a wide range of animal models it has been demonstrated that CLA exerts anticarcinogenic activity (Belury, 2002). Dietary CLA supplementation has been revealed to increase the activity and function of the immune system (Sugano et al., 1997) and to attenuate the negative effects of inflammatory reactions by inhibiting mRNA expression and production of proinflammatory cytokins by blood cells (Changhua et al., 2004).

In pigs the potential effect of conjugated linoleic acid on the rate of fat deposition in adipose tissue has been well documented (DeLany and West, 2000; Corino et al., 2002; Ostrowska et al., 2003). The mechanism of this phenomenon is attributed to the direct effect of CLA on the activity of key enzymes involved in mobilization and deposition of fat in adipocytes (Park et al., 1997). The effect of CLA on adipose tissue metabolism can be better understood by determining the blood concentration of some lipid fractions, fatty acids and hormones in blood plasma and the activity of enzymes involved in lipid metabolism in the adipose tissue of animals fed a diet supplemented with CLA isomers. One of these enzymes is $\Delta 9$-desaturase stearoyl-CoA, which is responsible for fatty acid synthesis, mainly monounsaturated fatty acids (MUFA). Corl et al. (2001) have proposed estimation of a desaturase index as the ratio between MUFA and the sum 
of saturated fatty acids (SFA) and MUFA. It has been shown that dietary CLA supplementation decreased the desaturase index as the result of the attenuation of the activity of $\Delta 9$-desaturase stearoyl-CoA (Smith et al., 2002).

Thyroid hormones, thyroxine $\left(\mathrm{T}_{4}\right)$ and triiodothyronine $\left(\mathrm{T}_{3}\right)$, belong to the most essential regulators of lipids metabolism in adipose tissue and their concentrations in blood plasma. These hormones affect the basal metabolic rate and thermogenic processes (Silva, 1995); thyroid hormones exert anabolic or catabolic properties at low or high concentrations, respectively (Eberhardt et al., 1980). With specific consideration of lipid metabolism, iodothyronines have an effect on synthesis, mobilization and degradation of lipids, although degradation is influenced more than synthesis (Pucci et al., 2000). The most important effects of iodothyronines on lipid metabolism include: 1 . enhanced utilization of lipid substrates, 2 . increased synthesis and mobilization of triglycerides stored in adipose tissue, 3 . increased concentrations of non-esterified fatty acids (NEFA), 4. augmented lipoprotein-lipase activity (Pucci et al., 2000). It has been established that in pigs, the blood concentrations of lipids and cholesterol depend on the animal breed, sex, age and nutrition (Barowicz et al., 2000). Recently, it has been shown that in fatteners during growth there is a strong relationship between genotype and thyroid activity with lipid and cholesterol levels in blood plasma. A gradual decrease in total lipids in blood plasma was correlated with a decrease in $\mathrm{T}_{3}$, the main metabolic hormone, in blood plasma (Migdał et al., 2003).

In pigs there have been no reported studies concerning simultaneous determination of lipids and thyroid hormone concentrations in blood plasma following dietary CLA supplementation. Therefore, the present experiment was designed to estimate the influence of supplementing diets with increasing CLA levels on lipid levels (i.e. triglycerides, total cholesterol, low density lipoprotein (LDL) and high density lipoprotein (HDL) fractions), fatty acid profile, and iodothyronine concentrations in blood plasma of fatteners. The main aim of the investigation was to study the interaction between dietary CLA and thyroid hormone activity to explain changes in lipid parameters in blood plasma. Moreover, the results of the experiment may provide valuable observations for human medicine concerning the effect of dietary CLA on lipid metabolism and thyroid function.

\section{MATERIAL AND METHODS}

\section{Animals and management}

The experiment was carried out on 50 fatteners of the Polish Large White breed with an initial body weight of $50 \pm 2 \mathrm{~kg}$, kept in individual pens equipped with automatic drinkers. During the experiment the pigs were fed ad libitum complete mixtures. 
Experimental design and treatment

Fatteners were randomly divided into 5 groups ( 5 gilts and 5 barrows per group). Treatment with CLA given at $0,0.5,1,1.5$ and $2 \%$ DM of the ration. Because of a similar higher fatty acid profile, a $2 \%$ sunflower oil supplement was used in the group given no CLA to balance the energy value of the complete diets (Table 1). Animals received a finisher diet used at Slaughter Pig Testing

Table 1. Fatty acids composition of conjugated linoleic acids (CLA) and sunflower oil (\% of acids sum) applied in the experiment

\begin{tabular}{lcc}
\hline Fatty acids & Sunflower oil & CLA \\
\hline C $12: 0$ & 0.024 & 0.169 \\
C $14: 0$ & 0.071 & 0.123 \\
C $16: 0$ & 5.99 & 4.14 \\
C $16: 1 n-7$ & 0.089 & 0.095 \\
C $18: 0$ & 3.03 & 1.12 \\
C $18: 1 n-9$ & 27.176 & 21.605 \\
C $18: 2 n-6$ & 61.86 & 3.02 \\
C $18: 3 n-6$ & - & 0.013 \\
C $18: 3 n-3$ & 0.80 & 0.153 \\
C $18: 2 c 9 t 11$ & 0.024 & 20.978 \\
C $18: 2$ t10c12 & 0.008 & 22.29 \\
C $18: 2 c 9 c 11$ & 0.008 & 18.53 \\
C $18: 2 t 9 t 11$ & 0.245 & 6.688 \\
C $20: 0$ & 0.19 & 0.915 \\
C 20:4 n-6 & - & - \\
C 20:5 n-3 & 0.004 & 0.009 \\
C 22:0 & 0.417 & 0.128 \\
C 22:1 & 0.064 & 0.019 \\
C 22:6 n-3 & - & - \\
Sum of CLA & 0.284 & 68.486 \\
\hline
\end{tabular}

Stations that contains wheat, triticale, maize, soyabean meal, minerals, Lutamix premix (BASF, Kutno) and a CLA supplement (Edenor UKD 6010, Henkel). CLA contained the isomers C 18:2 c9t11 (20.9\%), C 18:2 t10c12 (22.3\%), C 18:2 $c 9 c 11(18.5 \%)$ and $\mathrm{C} 18: 2 t 9 t 11(6.7 \%)$. The control group received sunflower oil (ZPT, Warsaw) containing, \%: SFA 6.6, MUFA 21.7 and PUFA $71.7(0.16 \%$ of n-3 PUFA and $3.0 \%$ of n-6 PUFA). The metabolizable energy (13.2 MJ) was calculated based on the diet composition, assuming tabular values for individual components (Nutrient Requirements of Pigs, 1993). The basal and amino acid compositions of the diets were determined according to AOAC (1990). The composition of feed mixtures was, \%: crude protein 16.2, crude fibre 3.3 , crude fat 1.9 , total phosphorus 0.63 , calcium 0.91 , lysine 0.9 , methionine with cystine 0.57 , and tryptophan 0.21 (Table 2). Throughout the 
Table 2. Composition and nutritive value of feed mixtures

\begin{tabular}{lc}
\hline Item & Composition, $\%$ \\
\hline Ingredient & \\
ground wheat & 40.0 \\
ground triticale & 22.8 \\
ground maize & 20.0 \\
soyabean meal (46\% CP) & 14.0 \\
limestone & 1.7 \\
dicalcium phosphate & 0.5 \\
vitamin-mineral premix (Lutamix & 1.0 \\
$\quad$ complete, BASF, Kutno, Poland) & \\
Calculated nutritive value & \\
metabolizable energy, MJ & 13.16 \\
crude protein, \% & 16.15 \\
crude fibre, \% & 3.30 \\
crude fat, \% & 1.88 \\
crude ash, \% & 4.72 \\
Ca, \% & 0.91 \\
total P, $g$ & 0.63 \\
available P, \% & 0.36 \\
Na, \% & 0.16 \\
lysine, \% & 0.90 \\
methionine+cystine, \% & 0.57 \\
treonine, \% & 0.56 \\
tryptophan, \% & 0.21 \\
\hline
\end{tabular}

experiment, the animals were fed in accordance with the Nutrient Requirements of Pigs (1993). Blood was sampled at approximately $105 \mathrm{~kg}$ body weight from the anterior caval vein into heparinized tubes. Blood plasma was obtained after centrifuging whole blood at $3000 \mathrm{rpm}$ for $10 \mathrm{~min}$. Plasma was then transferred into vials and frozen at $-28^{\circ} \mathrm{C}$.

\section{Analytical procedures}

The levels of triglycerides (TG), total cholesterol (TC) and HDL cholesterol were determined enzymatically using Cormay kits (Lublin, Poland). LDL cholesterol was calculated using the Friedewald formula: LDL $=$ TC - HDL - TG/5 (Friedewald et al., 1972). The composition of plasma fatty acids was determined using gas chromatography according to procedure 975.39 (AOAC, 1990) after extraction with a methanol and chloroform mixture (v/v 1:2). Determinations were carried on a TRACE GC ULTRA gas chromatograph (Electron Co., USA) with a SUPELCOWAX $10(30 \mathrm{~m} \times 0.25 \mathrm{~mm}$ I.D. $\times 0.25 \mu \mathrm{m}$ film thickeness $)$ column under the following conditions: helium as the carrier gas (flow rate 
$5 \mathrm{ml} / \mathrm{min}$ ), split flow $10 \mathrm{ml} / \mathrm{min}$, injector temperature $220^{\circ} \mathrm{C}$, column temperature $200^{\circ} \mathrm{C}$, detector temperature $250^{\circ} \mathrm{C}$.

The plasma level of thyroid hormones was determined by radioimmunoassay. Total $\mathrm{T}_{4}$, free $\mathrm{T}_{4}\left(\mathrm{FT}_{4}\right)$ and free $\mathrm{T}_{3}\left(\mathrm{FT}_{3}\right)$ were determined using commercial CIS kits (US Inc., USA): RIA-gnost ${ }^{\circledR} \mathrm{T}_{4}$, RIA-gnost ${ }^{\circledR} \mathrm{FT}_{4}$ and RIA-gnost ${ }^{\circledR} \mathrm{FT}_{3}$, in which anti- $\mathrm{T}_{4}$ or anti- $\mathrm{T}_{3}$ antibody-coated tubes are used. The sensitivity of the kits was $2.5 \mathrm{ng} / \mathrm{ml}, 0.5 \mathrm{pg} / \mathrm{ml}$ and $0.6 \mathrm{pg} / \mathrm{ml}$, respectively, with intra-assay coefficients of variation of $4.7,5.5$ and $5.0 \%$, respectively. The plasma concentrations of total $\mathrm{T}_{3}$ and $\mathrm{rT}_{3}$ were determined using the double antibody method. The antibodies used in the analyses were $\mathrm{Ab}-\mathrm{T}_{3}$ (Sigma; working titre 1:6000), $\mathrm{Ab}^{-\mathrm{rT}} \mathrm{T}_{3}(2 / 77$; titre 1:8000), and the second antibody against rabbit immunoglobulins (Ab-II; working titre: 1:30). Anti-rT ${ }_{3}$ antibodies were a gift from Prof. Jerzy Kosowicz (Medical Academy, Poznań), and the second ("antirabbit") antibody was obtained at the Department of Animal Physiology of the Agricultural University in Krakow after several immunizations of sheep with rabbit immunoglobulins. The analytical sample contained $100 \mu \mathrm{l}$ of blood plasma (or plasma free of iodothyronine, in which $\mathrm{T}_{3}$ or $\mathrm{rT}_{3}$ standard was dissolved), $100 \mu 1$ of isotope-labeled 125I-T or 125I-rT ${ }_{3}$ (spec. act. 135-165 mCi/mg; DuPont NEN, Belgium) and $100 \mu \mathrm{l}$ of appropriate primary antibody. After $24 \mathrm{~h}$ incubation at room temperature, $100 \mu \mathrm{l}$ $\mathrm{Ab}$-II was added to each tube and the samples were incubated for $30 \mathrm{~min}$. This was followed by adding $1 \mathrm{ml}$ of $18 \%$ polyethylene glycol (PEG; Sigma). The samples were mixed and centrifuged for $30 \mathrm{~min}(3000 \times \mathrm{g})$. After centrifugation, the supernatant was removed and the samples were measured in a gamma counter (LKB, Finland). The sensitivities of these two methods were 0.05 and $0.03 \mathrm{ng} / \mathrm{ml}$, with intra-assay coefficients of variation of 6.1 and $4.5 \%$, respectively.

\section{Statistical analysis}

The results were analysed statistically by two-way analysis of variance followed by Tukey's test using the Statgraphics Plus 4.0 computer program. The results were considered significant at $\mathrm{P}<0.05$ and highly significant at $\mathrm{P}<0.01$.

\section{RESULTS}

The effect of CLA supplementation on the level of blood lipid indicators in pigs is shown in Table 3. The use of CLA at $0.5-2.0 \%$ of the ration did not cause statistically significant changes in the blood levels of individual lipid fractions. However, the obtained data indicate a tendency towards increased concentrations of TG, TC and LDL cholesterol in the blood of CLA-supplemented pigs. Analysis of the effect of sex on these parameters studied showed that in barrows, plasma 
Table 3. Concentrations of lipid indicators in blood plasma of fatteners obtaining conjugated linoleic acid (CLA) in diet, $\mathrm{mg} / \mathrm{dl}$

\begin{tabular}{|c|c|c|c|c|c|c|c|c|c|c|}
\hline \multirow[t]{2}{*}{ Indicator } & \multicolumn{5}{|c|}{$\begin{array}{c}\% \text { of CLA addition to the diet } \\
n=10 \text { in each group }\end{array}$} & \multirow[t]{2}{*}{ SEM } & \multicolumn{2}{|c|}{ Sex } & \multirow[t]{2}{*}{ SEM } & \multirow{2}{*}{$\begin{array}{c}\text { Interaction } \\
\text { diet } \times \text { sex } \\
P \text { value }\end{array}$} \\
\hline & 0 & 0.5 & 1.0 & 1.5 & 2.0 & & gilts & barrows & & \\
\hline Triglycerides & 43.64 & 45.30 & 47.78 & 40.33 & 39.49 & 3.60 & $39.8 \mathrm{a}$ & $46.7 b$ & 2.27 & 0.16 \\
\hline \multicolumn{11}{|l|}{ Total } \\
\hline cholesterol & 75.61 & 87.17 & 84.64 & 81.81 & 81.55 & 3.34 & 80.7 & 83.5 & 2.11 & 0.33 \\
\hline HDL & 32.17 & 32.49 & 31.40 & 31.63 & 31.75 & 1.49 & 32.4 & 31.3 & 0.94 & 0.03 \\
\hline LDL & 34.71 & 45.61 & 43.68 & 42.11 & 41.90 & 2.83 & 40.3 & 42.8 & 1.73 & 0.81 \\
\hline
\end{tabular}

a,b $-\mathrm{P}<0.05$; SEM - standard error of mean

TG levels were significantly higher $(\mathrm{P}<0.05)$, with only an upward tendency for $\mathrm{TC}$ and LDL cholesterol.

Changes in the composition of fatty acids in the blood plasma of fatteners receiving different CLA rations are shown in Table 4 . The dietary CLA supplement of $0.5-2.0 \%$ caused a gradual increase in the CLA fraction in blood from 0.37 to $3.14 \%(\mathrm{P}<0.01)$. CLA had an effect on a significant $(\mathrm{P}<0.01)$ increase in the level of SFA, especially stearic acid (C 18:0;12.5 $\rightarrow 14.1 \%)$. Dietary CLA supplementation caused a significant $(\mathrm{P}<0.01)$ decrease in the level of MUFA, particularly oleic acid (C 18:1;24.2 $\rightarrow 15.3 \%)$ and PUFA, particularly n-6 PUFA, including linoleic acid (C 18:2; 32.2 $\rightarrow 27.4 \%$ ) and arachidonic acid (C 20:4; $8.3 \rightarrow 5.6 \%$ ), while significantly increasing the level of n-3 UFA, timnodonic acid $(\mathrm{C} 20: 5 ; 0.15 \rightarrow 0.27 \%)$ and $\mathrm{C} 22: 5(1.04 \rightarrow 1.31 \%)$. The increase in the dietary CLA level significantly lowered the n-6 PUFA to n-3 PUFA ratio in blood plasma from 18.2 to $13.2(\mathrm{P}<0.01)$. CLA also caused a significant $(\mathrm{P}<0.01)$ decrease in the $\Delta 9$-desaturase index from 0.48 in the control group to 0.36 in the group receiving $2 \%$ dietary CLA. Two-way ANOVA revealed significant interaction between the CLA-enriched diet and sex of the experimental animals, especially in the case of SFA $(\mathrm{P}<0.01)$, MUFA $(\mathrm{P}<0.02)$, PUFA $n-6 / n-3(\mathrm{P}<0.01)$ and the $\Delta 9$-desaturase index $(\mathrm{P}<0.04)$ (Table 4$)$. In comparison with control group values, only the $0.5 \%$ dietary CLA supplement significantly $(\mathrm{P}<0.01)$ increased the blood concentration of $\mathrm{T}_{4}$ and $\mathrm{T}_{3}$ in pigs: by 64 and $27 \%$, respectively (Table 5). The statistical analysis showed that the effect of CLA on $\mathrm{T}_{4}$ and $\mathrm{T}_{3}$ concentrations in blood depended on the sex of fatteners. Moreover, the analysis revealed that the $\mathrm{T}_{3}$ concentration in the plasma of barrows was significantly higher $(\mathrm{P}<0.05$; Table 5). No significant effect of CLA on $\mathrm{rT}_{3}, \mathrm{FT}_{4}$ and $\mathrm{FT}_{3}$ concentrations in the blood of the animals studied was found. 


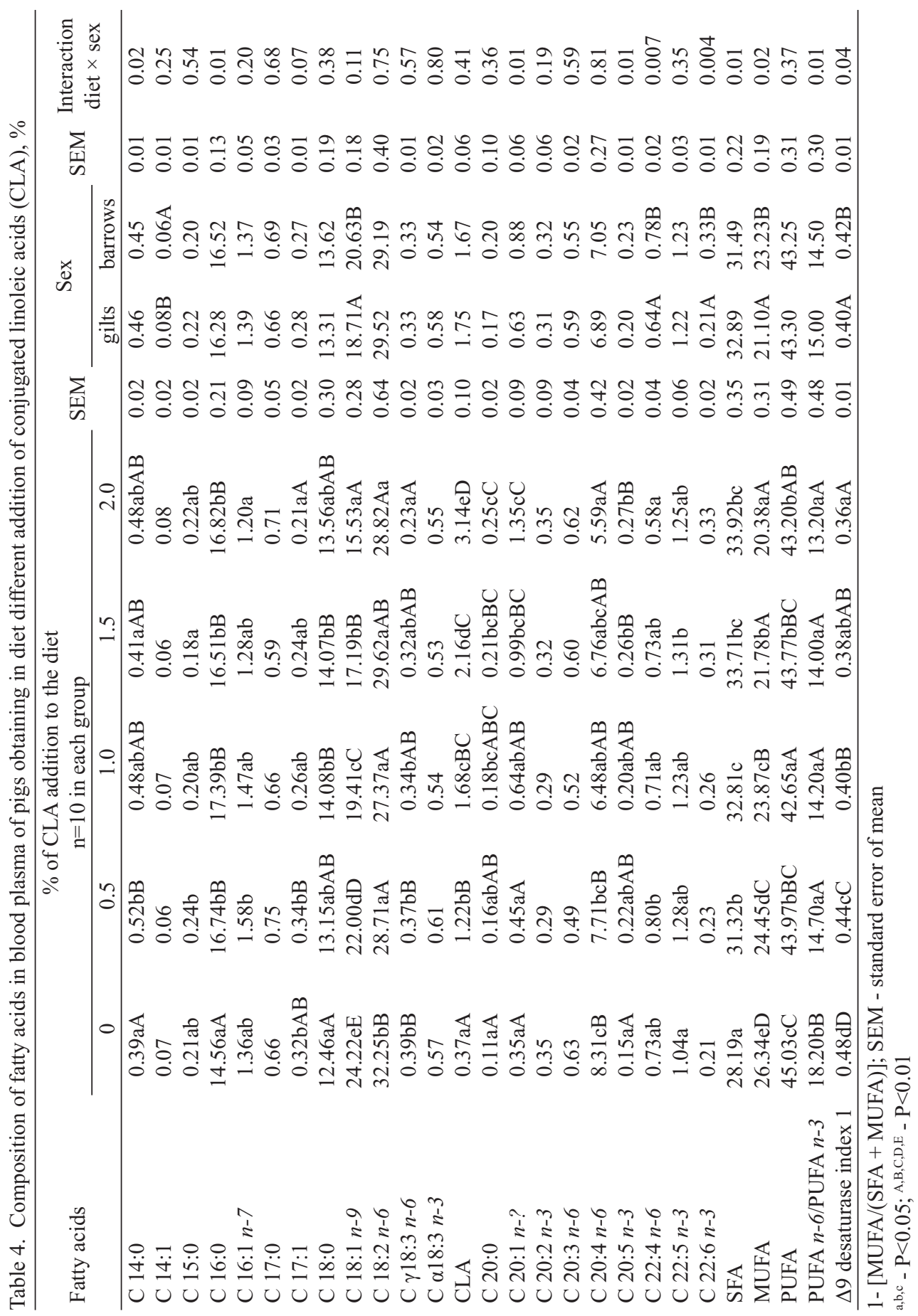


Table 5. Effect of different CLA addition in the fatteners' diet on thyroid hormone concentrations in blood plasma $(\mathrm{n}=10)$

\begin{tabular}{|c|c|c|c|c|c|c|c|c|c|c|}
\hline \multirow[t]{2}{*}{ Item } & \multicolumn{5}{|c|}{$\begin{array}{c}\% \text { of CLA addition to the diet } \\
n=10 \text { in each group }\end{array}$} & \multirow[t]{2}{*}{ SEM } & \multicolumn{2}{|c|}{ Sex } & \multirow{2}{*}{ SEM } & \multirow{2}{*}{$\begin{array}{c}\text { Interaction } \\
\text { diet } \times \text { sex } \\
P \text { value } \\
\end{array}$} \\
\hline & 0 & 0.5 & 1.0 & 1.5 & 2.0 & & gilts & barrows & & \\
\hline $\mathrm{T}_{4}, \mathrm{ng} / \mathrm{ml}$ & $18.86 \mathrm{~A}$ & $30.98 \mathrm{~B}$ & $16.72 \mathrm{~A}$ & $16.62 \mathrm{~A}$ & $23.86 \mathrm{AB}$ & 1.87 & 20.05 & 22.77 & 1.18 & 0.005 \\
\hline $\mathrm{T}_{3}, \mathrm{ng} / \mathrm{ml}$ & 1.00abAB & $1.27 \mathrm{bB}$ & $0.86 \mathrm{aA}$ & $1.22 \mathrm{bAB}$ & $0.97 \mathrm{ab} \mathrm{AB}$ & 0.07 & $0.99 \mathrm{a}$ & $1.14 \mathrm{~b}$ & 0.04 & 0.02 \\
\hline $\mathrm{rT}_{3}, \mathrm{ng} / \mathrm{ml}$ & 0.45 & 0.46 & 0.51 & 0.49 & 0.46 & 0.02 & 0.45 & 0.50 & 0.01 & 0.08 \\
\hline $\mathrm{FT}_{4}, \mathrm{pg} / \mathrm{ml}$ & 2.33 & 13.46 & 12.60 & 13.27 & 14.22 & 0.80 & 12.72 & 13.63 & 0.50 & 0.26 \\
\hline $\mathrm{FT}_{3}, \mathrm{pg} / \mathrm{ml}$ & 3.16 & 3.21 & 3.23 & 3.15 & 3.17 & 0.19 & 3.11 & 3.25 & 0.12 & 0.29 \\
\hline
\end{tabular}

a,b - $\mathrm{P}<0.05$; A,B - P $<0.01$; SEM-standard error of mean

\section{DISCUSSION}

Supplementing CLA is an effective method of changing the composition of fatty acids and lipids in pig blood and tissues (Ostrowska et al., 2003). In the present study, the CLA preparation increased the level of saturated acids, mainly C 18:0. These results concur with earlier studies that found a positive effect of CLA on the saturation of fatty acids in pig lipids (Migdał et al., 2004). The dietary CLA supplement was found to increase the level of n-3 UFA and to reduce the level of n-6 acids (Smith et al., 2002). A similar effect was observed in the present study, i.e. an increase in the level of n-3 C 20:5 and C 22:5 acids and a decrease in the level of n-6 acids, particularly C18:2 and C 20:4. Bani and Martin (1998) suggested that CLA selectively affects the elongation of $n-3$ acids and increases the degradation of $n-6$ acids. In studies with rats, CLA was shown to protect $n-3$ acids and to increase the utilization of $\mathrm{n}-6$ acids ( $\mathrm{Li}$ and Watkins, 1998). Changes in the level of C 18:3 and C 18:2 acids of the n-3 and n-6 series influence desaturase activity and thus lead to oxidation of double bonds and elongation of the carbon chain. The relationships between n- 6 and n-3 PUFA are illustrated by their mutual proportions (n-6 PUFA/n-3 PUFA), the decrease of which is inversely proportional to the amount of CLA in the diet. A similar relationship between the amount of dietary CLA and the proportion of UFA in blood was shown by Ostrowska et al. (2003). In the present study we observed a diet-dependent effect of CLA on reducing the blood level of MUFA. A similar effect of CLA on the blood level of MUFA, which can be attributed to a gradual decrease in stearoyl-CoA desaturase activity, was noted in previous feeding trials (Smith et al., 2002). This suggestion is confirmed by a gradual decrease in the $\Delta 9$-desaturase index in animals receiving CLA (Table 4). The direct replacement of fatty acids with dietary CLA and its effect on desaturase and lipase activity are probably the main reasons for the changes observed in the fatty acid profile of blood plasma. In earlier studies, CLA was viewed as a hypocholesterolaemic factor that reduces atherosclerosis in rodents, mainly rats and rabbits (Corino et al., 2002). 
In the present study, total cholesterol and LDL fractions in plasma of Polish Large White breed fatteners were similar to those found in the Pietrain breed, but were by about $20 \%$ lower in comparison with Duroc and Hampshire pigs of the same age (Migdał et al., 2003). CLA had no significant effect on the concentration of particular lipoprotein fractions, although there was a tendency towards increased levels of triglycerides, total cholesterol and HDL cholesterol. In pigs, similar changes in the blood lipid levels were observed after the administration of $1.65 \%$ CLA in the diet by Stangl et al. (1999). Munday et al. (1999) found aortic fatty streaks in mice fed CLA. In contrast, Sugano et al. (1997) found no differences in the concentration of HDL and total cholesterol in rats fed CLA at $1 \%$ of the ration. Based on the above results it is difficult to compare the quality and extent of changes in the lipoprotein profile with those reported in other studies, because lipid indicators vary according to not only the experimental diet but also the species and sex of the animals studied. Most of the above-mentioned studies investigated the effects of mixtures of a large number of CLA isomers, however, several lines of evidence indicate that the effect of CLA on plasma lipid profiles may depend on the effects of individual CLA isomers or the proportion between $c 9 t 11$ and $t 10 c 12$ CLA isomers in a diet. For instance, Tricon et al. (2004) showed the hyperlipidaemic effect of $t 10 c 12$ CLA and hypolipaemic properties of $c 9 t 11$ CLA isomers in blood plasma of healthy humans. A similar hyperlipidaemic effect following treatment with $t 10 c 12-C L A$ diet was found in mice (Arbones-Mainar et al., 2006). Further investigations are needed to explain the effect of individual CLA isomers on lipid profiles in the blood plasma of growing pigs.

In the present study we found a significant increase in the plasma concentrations of $\mathrm{T}_{4}$ and $\mathrm{T}_{3}$ in pigs receiving the lowest CLA dose $(0.5 \%)$. Where higher CLA doses were given, changes in the blood levels of $\mathrm{T}_{4}$ and $\mathrm{T}_{3}$ were not statistically significant in relation to control group values. CLA had no effect on the levels of $\mathrm{FT}_{4}, \mathrm{FT}_{3}$ or $\mathrm{rT}_{3}$. The level of $\mathrm{T}_{3}$ was significantly higher in the blood of barrows than gilts, which may be related to the higher basal metabolic rate in the males (Danforth and Burger, 1989). Sawosz et al. (2005) reported that the blood concentration of iodothyronines in pigs is correlated with the level of dietary energy. Changes in the blood level of $\mathrm{T}_{4}$ reflect thyroid activity and $\mathrm{T}_{4}$ utilization in peripheral tissues (mainly in the liver and kidneys). Meanwhile, changes in the $\mathrm{T}_{3}$ level are caused by both the activity of the thyroid (from which approximately $30 \%$ of this hormone originates) and the activity of $\mathrm{D} 1$ and $\mathrm{D} 3$ deiodinases, which are responsible for the conversion of $\mathrm{T}_{4}$ into $\mathrm{T}_{3}$ and $\mathrm{rT}_{3}$ in peripheral tissues and then into 3,3'- $\mathrm{T}_{2}$ (Wassen et al., 2004). It can therefore be suggested that the increased blood concentration of $\mathrm{T}_{4}$ and $\mathrm{T}_{3}$ in pigs fed CLA is related to a direct effect of CLA on the activity of the hypothalamic-pituitary-thyroid axis and/or deiodinase activity. On the other hand, the lack of significant changes in the level of free iodothyronines (i.e. $\mathrm{FT}_{4}$ and $\mathrm{FT}_{3}$ ) suggests that despite the effect of CLA (at low concentrations) on the blood level of total $\mathrm{T}_{4}$ and $\mathrm{T}_{3}$, these changes are 
physiologically unimportant because body cells can be normally supplied with both free iodothyronines.

\section{CONCLUSIONS}

The supplementation of fatteners with dietary CLA alters mainly the profile of fatty acids in blood but has no significant effect on the levels of triglycerides, total cholesterol and cholesterol fractions. The lack of significant changes in the concentration of free thyroxine and triiodothyronine indicates that CLA supplementation may not significantly change the body's thyroid homeostasis.

\section{REFERENCES}

AOAC, 1990. Official Methods of Analysis, Association of Official Analytical Chemists. $15^{\text {th }}$ Edition. Arlington, VA

Arbones-Mainar J.M., Navarro M.A., Guzman M.A., Arnal C., Surra J.C., Acin S., Carnicer R., Osada J., Roche H.M., 2006. Selective effect of conjugated linoleic acid isomers on atherosclerotic lesion development in apolipoprotein E knockout mice. Atherosclerosis 189, 318-327

Banni R.S., Martin J.C., 1998. Conjugated linoleic acid and metabolites. In: J.L. Sebedio, W.W. Christie (Editors). Trans Fatty Acids in Human Nutrition. The Oily Press Ldt., Dundee (Scotland), pp. 28-56

Barowicz T., Brzóska F., Pietras M., 2000. Hypocholesterolemic effect of fat feed in the diets of growing pigs (in Polish). Med. wet. 56, 746-749

Belury M., 2002. Inhibition of carcinogenesis by conjugated linoleic acid: potential mechanisms of action. J. Nutr. 132, 2995-2998

Changhua L., Jindong Y., Defa L., Lidan Z., Shiyan Q., Jianjun X., 2004. Conjugated linoleic acid attenuates the production and gene expression of proinflammatory cytokines in weaned pigs challenged with lipopolysaccharide. J. Nutr. 135, 239-244

Corl B.A., Baumgard L.H., Dwyer D.A., Griinari J.M., Philips B.S., Bauman D.E., 2001. The role of $\Delta 9$-desaturase in the production of cis-9, trans-11 CLA monounsaturated fatty acids. J. Nutr. Biochem. 12, 622-630

Corino C., Marout J., Magni S., Pastorelli G., Rosi F., 2002. Influence of dietary conjugated linoleic acid on growth, meat quality, lipogenesis, plasma leptin and physiological variables of lipid metabolism in rabbits. J. Anim. Sci. 80, 1020-1028

Danforth Jr. E., Burger A.G., 1989. The impact of nutrition on thyroid hormone physiology and action. Annu. Rev. Nutr. 9, 201-227

DeLany J.P., West D.B., 2000. Changes in body composition with conjugated linoleic acid. J. Amer. Coll. Nutr. 19, 487-493

Dugan M.E.R., Aalhus J.L., Kramer J.K.G., 2004. Conjugated linoleic acid pork research. Amer. J. Clin. Nutr. 79, Suppl., 1212S-1216S

Eberhardt N.L., Apriletti J.W., Baxter J.D., 1980. The molecular biology of thyroidal hormone action. In: G. Litwack (Editor). Biochemical Actions of Hormones. Vol. 7. Academic Press, New York, pp. 311-394 
Friedewald W.T., Levy R.I., Fredrickson D.S., 1972. Estimation of the concentration of low-density lipoprotein cholesterol in plasma, without use of the preparative ultracentrifuge. Clin. Chem. $18,499-502$

Li Y., Watkins B.A., 1998. Conjugated linoleic acids alter bone fatty acid composition and reduce ex vivo prostaglandin E2 biosynthesis in rats fed n-6 or n-3 fatty acids. Lipids 33, 417-425

Migdał W., Paściak P., Wojtysiak D., Barowicz T., Pieszka M., Pietras M., 2004. The effect of dietary CLA supplementation on meat and eating quality, and the histochemical profile of the $m$. longissimus dorsi from stress susceptible fatteners slaughtered at heavier weights. Meat Sci. 66, 863-870

Migdał W., Sechman A., Rząsa J., Borowiec F., Fandrejewski H., Raj S., Weremko D., Skiba G., 2003. Changes in serum concentration of thyroid hormones, total lipids and cholesterol in fatteners. Med. wet. 59, 879-883

Munday J.S., Thopson K.G., James K.A., 1999. Dietary conjugated linoleic acids promote fatty streak formation in the C57BL/6 mouse atherosclerosis model. Brit. J. Nutr. 81, 251-255

Nutrient Requirements of Pigs. Nutritive Value of Feedstuffs (in Polish), 1993. The Kielanowski Institute of Animal Physiology and Nutrition, Polish Academy of Sciences (Editor). Jabłonna (Poland)

Ostrowska E., Cross R.F., Muralitharan M., Bauman D.E., Dusdea F.R., 2003. Dietary conjugated linoleic acid differentially alters fatty acid composition and increases conjugated linoleic acid content in porcine adipose tissue. Brit. J. Nutr. 90, 915-928

Park Y., Albright K.J., Storkson J.M., Cook M.E., Pariza M.W., 1997. Effects of conjugated linoleic acid on body composition in mice. Lipids 32, 853-858

Pucci E., Chiovato L., Pinchera A., 2000. Thyroid and lipid metabolism. Int. J. Obes. Relat. Metab. Disord. 24, Suppl. 2, 109-112

Sawosz E., Chwalibog A., Skomiał J., Kosieradzka I., Zięcik A.J., 2005. The effect of dietary energy concentration on the hormone profile and lipid metabolism in growing pigs. J. Anim. Feed Sci. 14, Suppl. 1, 393-396

Silva J.E., 1995. Thyroid hormone control of thermogenesis and energy balance. Thyroid 5, 481-492

Smith S.B., Hively T.S., Cortese G.M., Han J.J., Chung K.Y., Castenada P., Gilbert C.D., Adams V.L., Mersmann H.J., 2002. Conjugated linoleic acid depressed the delta 9 desaturase index and stearoyl coenzyme A desaturase enzyme activity in porcine subcutaneous adipose tissue. J. Anim. Sci. 80, 2110-2115

Stangl G.I., Müller H., Kirchgessner M., 1999. Conjugated linoleic acid effects on circulating hormones, metabolites and lipoproteins, and its proportion in fasting serum and erythrocyte membranes of swine. Eur. J. Nutr. 38, 271-277

Sugano M., Tsujita A., Yamasaki M., Yamada K., Ikeda I., Kritchevsky D., 1997. Lymphatic recovery, tissue distribution, and metabolic effects of conjugated linoleic acid in rats. Nutr. Biochem. 8, $38-43$

Tricon S., Burge G.C., Kew S., Banerjee T., Russell J.J., Jones E.L., Grimble R.F., Williams C.M., Yaqoob P., Calder P.C., 2004. Opposing effects of cis-9,trans-11 and trans-10,cis-12 conjugated linoleic acid on blood lipids in healthy humans. Amer. J. Clin. Nutr. 80, 614-620

Wassen F.W., Klootwijk W., Kaptein E., Duncker D.J., Visser T.J., Kuiper G.G., 2004. Characteristics and thyroid state-dependent regulation of iodothyronine deiodinases in pigs. Endocrinology $145,4251-4263$ 